\title{
Poverty incidence in Sri Lanka: Overview, trends, challenges and opportunities
}

\author{
Wanninayake Mudiyanselage Semasinghe \\ Department of Economics, University of Kelaniya, Kelaniya, Sri Lanka
}

\section{Email address:}

sema23@kln.ac.lk

\section{To cite this article:}

Wanninayake Mudiyanselage Semasinghe. Poverty Incidence in Sri Lanka: Overview, Trends, Challenges and Opportunities. Humanities and Social Sciences. Vol. 2, No. 5, 2014, pp. 132-138. doi: 10.11648/j.hss.20140205.12

\begin{abstract}
Poverty is one of the major socioeconomic issues that Sri Lanka has been attempting to tackle in the past six decades. Successive governments of the country have given highest priority to alleviate poverty and to sustain socioeconomic advancement of the country. The aim of this paper is to examine the trends of poverty incidence of the country and to identify the future challenges and opportunities that have opened up for poverty alleviation. The assessment was focused mainly on the income dimension of poverty. Secondary data published by the Department of Census and Statistics based on its Households Income and Expenditure Surveys and the data published by the Central Bank of Sri Lanka were used in the analysis. The data reveals that poverty incidence has shown a gradual declining trend during the past ten-fifteen years. Several factors including economic growth, workers' remittance, targeted poverty alleviation programs, increasing employment opportunities, improvement of socioeconomic infrastructure can be identified as the causal factors of this progress. Sustaining the declining trend and overcoming the disparity of poverty incidence among geographical locations are key challenges that should be addressed, appropriately. The end of the war the country presents several opportunities to free the country of income poverty.
\end{abstract}

Keywords: Public Policy, Poverty Alleviation, Economic Growth, Workers Remittance, Socioeconomic Infrastructure

\section{Introduction}

Sri Lanka is an island nation in South Asia and it is home to little more than twenty million people. Of them, 72 percent are living in rural sector which is known as relatively disadvantaged area for a long period of time, in terms of economic and social infrastructure and many other conveniences enjoyed by its urban counterpart; but much crucial sector for overall development of the nation. On the contrary, urban population of the country is only about 15 percent. Rest of the population is living in the so-called estate sector. Sri Lanka was a British colony when it regained its political independence in 1948. Since then for over past six and half decades, successive governments that came into power made various efforts and tested alternative policy notions to bring the country to the existing shape. The civil war persisted for over three decades was the major cause that interrupted the progress of the country and harmed largely to the economic and social life of the nation. By paying huge cost in terms of physical resources and human lives, at present the civil war has ended up.
Consequently, it has opened a great opportunity to work for the progress of the country.

Poverty is one of the greatly discussed phenomena within the economic, political as well as social arena in Sri Lanka recently, as in most other developing countries. This is mainly because the incidence of poverty has been identified as one of the central issues that the country has encountered and, as a major obstacle to achieve socioeconomic development goals and to sustain political stability.

As one of the first developing nations that understood the multidimensional nature of poverty, a number of poverty alleviation strategies have been implemented in Sri Lanka since its political independence. These strategies addressed not only the income dimension of poverty but also other aspects such as education, health and housing.

The Janasaviya (Strengthening People) program implemented in 1989 is the first ever targeted poverty alleviation strategy. It was succeeded by the Samurdhi (literally 'Prosperity') program in 1995 with the shift of political power from United National Party (UNP) to 
Peoples' Alliance (PA) at the national election held in 1994. This is the first program which targeted the poverty in the entire country simultaneously. In addition to the Samurdhi program, at present the Divi Neguma program is in operation covering all parts of the country aiming at uplifting the living conditions of the poor. Besides these targeted poverty alleviation programs, one of the central goals of all development strategies of the country is to address the incidence of poverty.

When considering these broad-based efforts, the question arises as to what has happened to the course of such poverty alleviation efforts, and whether these efforts have achieved their goals. The overall objective of the present article is to examine the level of poverty incidence of the country at present. In addition to that it intends to identify the trends of poverty incidence, challenges encountered and opportunities which have opened up for poverty alleviation.

The analysis is mainly based on the data published by the Department of Census and Statistics (DCS) through its Households Income and Expenditure Surveys (HIESs). The latest survey was conducted in 2009/10, three years since the survey in 2006/07.

As we all are aware, the measures of poverty depend on how poverty is defined or perceived. As the present analysis focuses mainly on the income dimension of poverty, it is based on the FGT (Foster-Greer-Thorbecke) class of poverty measures, focusing mainly on the Headcount Ratio (HCR) and Poverty Gap Index (PGI).

\section{Poverty Incidence at National and Sectoral Levels: Lowest Level of the History}

As Table 1 reveals, only about 8.9 percent of the total population of the country is poor according to the official poverty line (Rs. 3028 real total expenditure per person per month in 2009/10). This means that income of 8.9 percent of the individuals is inadequate to meet the specific nutritional requirements and to consume other essential non-food items. In fact, this is the lowest poverty rate recorded so far in the history of the country.

Table 1. Poverty incidence in Sri Lanka and by sectors-2009/10

\begin{tabular}{ll}
\hline Sector & Head-count Ratio (HCR) \\
\hline Urban & 5.3 \\
Estate & 9.4 \\
Rural & 11.4 \\
Sri Lanka & 8.9 \\
\hline
\end{tabular}

Source: Department of Census and Statistics, HIES-2009/10

At the sectoral level poverty incidence is highest in the estate sector (11.4\%) while lowest in the urban sector $(5.3 \%)$. Rural sector (9.4\%) is in between these two sectors. These are also the lowest rates of poverty recorded in the history at the sectoral level.

As the data reveals, the contribution of the rural sector to total poverty is 84.7 per cent. About 1.53 million individuals are poor in this sector. The number of poor in the estate sector is about 117,000 while the number in urban sector is about 153,000 . The number of the poor in the rural sector is ten times higher than that of the estate sector and 13 times than that of the urban sector (DCS, 2011). Thus, the population of each sector and the total number of the poor reveals that the poverty burden is highest in the rural sector and the lowest in the urban sector.

\section{Distribution of Poverty Incidence at the District level}

The civil war continued since the 1980 s mainly in the Northern and Eastern provinces in the country which prevented conducting countrywide surveys. After approximately three decades, the survey in 2009/10 covered 22 districts out of 25 . Three districts, namely Mannar, Mullaitivu and Kilinochchi, were not included in this survey, partly due to the incomplete resettlement process and the absence of a proper administrative body to support such a survey. The distribution of poverty at district level is given in the following Table.

Table 2. Poverty incidence at the district level-2009/10.

\begin{tabular}{|c|c|c|c|c|c|}
\hline Province & District & HCR & Province & District & HCR \\
\hline \multirow{3}{*}{ Western } & Colombo & 3.6 & \multirow{3}{*}{ North-western } & Kurunegala & 11.7 \\
\hline & Gampaha & 3.9 & & Puttalam & 105 \\
\hline & Kalutara & 6.0 & & & \\
\hline \multirow{3}{*}{ Central } & Kandy & 10.3 & \multirow{3}{*}{ North- central } & & \\
\hline & Matale & 11.5 & & Anuradnapura & $\begin{array}{l}5.1 \\
5.8\end{array}$ \\
\hline & Nuwara-eliya & 7.6 & & Polonnaruwa & \\
\hline \multirow{3}{*}{ Southern } & Galle & 10.3 & \multirow{3}{*}{ Uva } & Badulla & 13.3 \\
\hline & Matara & 11.2 & & Monaragala & 14.5 \\
\hline & Hambantota & 6.9 & & Mionaragala & 14.5 \\
\hline \multirow{2}{*}{ Northern } & Jaffna & 16.1 & \multirow{2}{*}{ Sabaragamuwa } & Ratnapura & 10.5 \\
\hline & Vavuniya & 2.3 & & Kegalle & 10.8 \\
\hline \multirow{3}{*}{ Eastern } & Batticaloa & 20.3 & & & \\
\hline & Amapara & 11.8 & & & \\
\hline & Trincomalee & 11.7 & & & \\
\hline
\end{tabular}

Source: Department of Census and Statistics, HIES-2009/10 
As per the Table 2, poverty incidence is highest in Batticaloa and Jaffna districts. This is natural because they are the most war affected districts of the country during the three decades of conflict, with extensive and prolonged damage to the socio-economic infrastructure as well as to the livelihood of the people of these districts. Thus, restoration of the lives of these people will take a reasonable period of time. The situation may be worst in Mannar, Mulative and Kilinochchi districts, which were not included into the survey. The unexpected situation of Vavuniaya district, another war affected district which was included into the survey for the first time, may be due to the biasness of the sample.

As found earlier, Badulla and Monaragala are the largely poor districts; both are in the Uva Province, which comprises mostly rural areas. After Vavuniya, the lowest poverty rate is recorded in Colombo District, followed by Gampaha. These two districts have accrued the greatest benefits from the development projects of both public and private sectors over a long period. Most of economic activities of the country are centred on the Western Province which includes these two districts. In fact, the Western Province is the economic and administrative hub of the country, contributing nearly half of the country's GDP(CBSL, 2010). Income earning opportunities for the people in these districts are higher than in other districts. Indeed, poverty incidence is high in Ampara, Kurunegala, Matara, Matale, Galle, Trincomalee, Puttalam, Kandy, Ratnapura and Kegalle districts, although the poverty headcount is less than in Monaragala and Badulla. The main economic activity of these districts is agriculture. From these, Ampara, Kurunegala and Trincomalee are the main paddy farming districts.

Another important fact revealed by the data in $2009 / 10$ is that the headcount index of 14 districts out of the 22 surveyed districts is higher than the national headcount index. This implies that a high incidence of poverty exists in a large part of the country. This part represents 58 percent of the total, largely non-urban population. At the same time, the urban population is relatively large in the districts that show a positive performance. This indicates that poverty incidence in Sri Lanka is geography- specific.

\section{Poverty Trends: Significant Declining Trend of Poverty Incidence}

Figure 1 below shows the poverty trend at the national level over the past two decades from 1990/91.

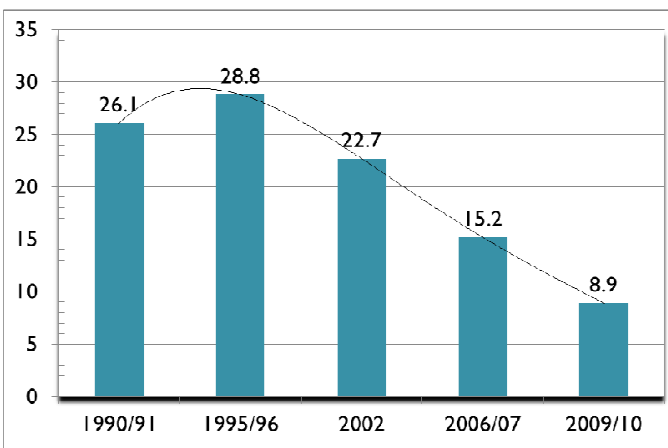

Source: Department of Census and Statistics, HIES-2009/10

Figure 1. Trends of poverty incidence - 1990/91-2009/10

As per the Figure 1, the poverty head-count has decreased gradually from 1995/96 revealing a declining trend of poverty incidence in the country. Overall, the poverty head-count ratio has dropped by 66 per cent from 26.1 per cent in $1990 / 91$ to 8.9 percent by $2009 / 10$. Headcount has dropped by 41 percent within the last three years from $2006 / 07$. It is the highest drop ever recorded in recent decades.

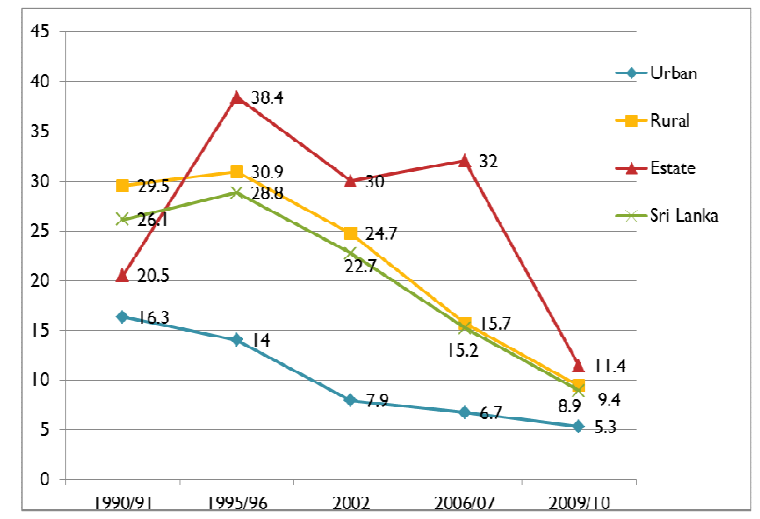

Source: Department of Census and Statistics, HIES-2009/10

Fig 2. Poverty head-count ratio by sectors

The drop in poverty levels in the rural and estate sectors has contributed significantly towards this progress. As Fig 2 shows, the poverty head-count ratio of these two sectors has declined gradually since 1995/96. Overall, the largest decline of head-count is recorded from the estate sector, which has declined by 27 percentage points (70\%) from 38.4 percent in $1995 / 96$ to 11.4 percent in $2009 / 10$ with a little increase in 2006/07. Within a mere three years from $2006 / 07$, the head-count in this sector has declined substantially by 64 percent. This decline is believed to be a result of the relative fall of food prices and an increase in the employment and wages in the estate sector since $2006 / 07$. Within the period from $1995 / 96$ to $2009 / 10$, rural poverty has also dropped approximately by 21 percentage points $(70 \%)$. This decline is largely a result of the high growth of agricultural sector and the development of infrastructure that integrates rural and urban markets 
(SLCB, 2011). In contrast, urban poverty has declined only by 8.7 percentage points $(62 \%)$.

All districts except Ampara and Batticaloa have achieved significant progress in terms of poverty reduction during the last two decades (This excludes the Jaffna, Vavuniya and Trincomalee districts which were included in the survey for the first time). Although in different proportions, the poverty head-count has declined in all these districts. The highest decline in the last three years from 2006/07 is recorded from the Nuwara-Eliya (78\%), which comprises a large estate population. Undoubtedly, the improvement of working conditions, increased working days and daily wages etc. during the past few years has contributed to this progress. Among others, Anuradhapura (62\%), Ratnapura (61\%), Monaragala (56\%), Kalutara (54\%), Polonnaruwa $(54 \%)$ and Hambantota $(46 \%)$ districts also have progressed significantly. In fact, all these districts had a large poor population by the year 2006/07. One of the distinctive features of these districts is its agriculture-based economy, with a considerably high percentage of its population employed in the agricultural sector. For example, the agricultural population in Nuwara Eliya, Anuradhapura, Ratnapura, Moneragala and Polonnaruwa districts is 68 per cent, 64 percent, 47 percent, 55 percent and 47 percent, 55 percent and 47 percent, respectively. Growth of agricultural productivity as well as sufficiently high market price particularly for paddy contributed to the increase in the income levels of farming families, thus freeing them from poverty. Though the agricultural sector grew only by 0.5 per cent during the $2001-2005$, it has grown by 5.5 per cent during 2006-2010.

Hambantota is another district that has gained remarkable progress in terms of poverty alleviation. As it is mainly a dry area and was highly a marginalised district for over a long period of time, there was a high level of poverty incidence. About eight years ago, 1 out of every 3 persons was poor in this district. By 2010 it has reduced to 7 out of every 100 . The poverty head-count has declined by 79 percent within eight years since 2002 . Undoubtedly, this progress of poverty reduction is largely a result of the massive development projects such as the harbour, the airport, the Southern expressway, and the highway network, which are being implemented throughout the district since 2005 .

The survey data reveal that the poverty incidence of Ampara and Batticaloa districts has increased during the three years from 2006/07. However, this increase of the head-count is most probably a result of the increase of the survey coverage of the $2009 / 10$ survey compared to that of 2006/07.

\section{Poverty Shortfall: Depth of Poverty}

Poverty shortfall indicates the depth of poverty. In other words it measures how poor the poor are? The gap indicates the amount of money required to free a poor from poverty. This information is very useful important than the information provided by head-count index in policymaking. Table 3 below describes the poverty shortfall at the country level as well as at the sectoral level and how it changes during the two survey periods.

\begin{tabular}{lllll} 
Table 3. Poverty shortfall Sri Lanka and by sector $-2006 / 07-2009 / 10$ \\
\hline \multirow{4}{*}{ Sector } & \multicolumn{3}{l}{ Poverty shortfall (Rs. per month) } \\
\cline { 2 - 5 } & $\begin{array}{l}\text { Total funds required } \\
\text { (millions) }\end{array}$ & \multicolumn{3}{c}{$\begin{array}{l}\text { Average funds required } \\
\text { per person }\end{array}$} \\
\cline { 2 - 5 } & $\mathbf{2 0 0 6 / 0 7}$ & $\mathbf{2 0 0 9 / 1 0}$ & $\mathbf{2 0 0 6 / 0 7}$ & $\mathbf{2 0 0 9 / 1 0}$ \\
\hline Urban & 78 & 108 & 423 & 680 \\
Rural & 1,041 & 885 & 452 & 578 \\
Estate & 138 & 67 & 434 & 569 \\
Sri Lanka & 1,257 & 1,060 & 448 & 587 \\
\hline
\end{tabular}

Source: Department of Census and Statistics, HIES-2006/07 and 2009/10

In spite of the effects of inflation, population growth and increased survey coverage when compared to $2006 / 07$ survey, total funds required to free the poor from poverty has decreased significantly in the three year period by about 16 per cent, from Rs. 1257 millions in 2006/07 to Rs. 1060 millions in 2009/10. However, the total funds required for the urban sector have increased by about 38 percent. This is due to the substantial increase in the average funds required per person in this sector. The average funds required per person in urban sector have increased by about 60 percent during this period. This is undoubtedly due to the high inflationary effect of the urban sector compared with the other sectors.

\section{Growth - Poverty Relation}

Economic growth is considered one of the key factors that contribute to reduce poverty. Literature on growthpoverty relation is abundant. Many argue that growth leads to reduced poverty in developing countries in several ways. The most popular argument in favor of this relationship is the 'trickle-down effect' of growth (Kakwani and Pernia, 2000). According to this argument, benefits of growth first reach the rich and then trickle down to the poor as the spending of the rich. Growth affects poverty directly as well as indirectly. It increases the income of the poor directly. This is called the 'income effect'. In fact, growth expands the capacity of the economy by increasing employment opportunities. This in turn results in the increased of income of the poor. Next is the multiplier effect of growth. Growth increases the government revenue, which reaches the poor through public investment in socioeconomic infrastructure and subsidies. However, growth alone does not reduce poverty. What happens to poverty with growth depends on what happens to the distribution of income and consumption (Angus Deaton, 2007: 9). In other words, who contributes to the growth? This is the 'distributional effect of growth'. If the benefits of growth are distributed adversely, growth may result in increasing relative poverty. As Kuznets' inverted Uhypothesis demonstrates, growth may cause to increase inequality first through the reallocation of resources and 
secondly by increasing poverty. Further, the effect of growth on poverty depends on the sectoral composition of growth (Datt and Ravallion, 1998). In other words, which sector contributes to the growth? If growth depends more on the agricultural sector than the non-agricultural sector, rural poor may benefit.

Although poverty rates are shown a declining trend during the past two decades from 1990/91, economic growth in the country does not show such a steady trend. Instead, it has fluctuated between -1.5 and 8 percent. For the first time since independence, economic growth recorded a negative value of 1.5 in 2001. Indeed it was largely caused by the civil war that existed at the time. A terrorist attack on the Katunayake International Airport in 2001 caused considerable damage to the economy. Repercussions of this attack lasted over several years. However, in general, a relatively healthy growth performance could be seen with an average annual per capita GDP growth of 5.5 percent between 2002 and 2010, and of 4.4 between 1990 and 2002. Even amidst the brutal civil war, the macroeconomic environment that existed in the country helped to achieve these high rates of economic growth in recent times.

Table 4. Poverty Incidence and GDP growth rate

\begin{tabular}{lll}
\hline HIES & Poverty & Average GDP \\
\hline Survey Year & HCI & growth rate \\
\hline $1990 / 91$ & 26.1 & 3.5 \\
$1995 / 96$ & 28.8 & 5.2 \\
2002 & 22.7 & 4.1 \\
$2006 / 07$ & 15.2 & 6.4 \\
$2009 / 10$ & 8.9 & 5.8 \\
\hline
\end{tabular}

Source: Department of Census and Statistics, HIESs, Central Bank of Sri Lanka, Annual Reports

By examining the headcount index and the GDP growth rates together, a close relationship could be identified between the two. The correlation coefficient between these two variables is -0.65 , implying an inverse relationship between the GDP growth rate and the poverty rate. This empirical order is compatible with the theoretical and general acceptance that growth can reduce the incidence of poverty directly as well as indirectly. Hence, economic growth can be identified as one of the factors that contributed to bring the incidence of poverty down in recent years.

The contribution of the agricultural sector's growth to the growth of GDP during the past few years was relatively high compared to 1990 s and early 2000 s. In particular, paddy production has increased by 32 percent between 2005 and 2010. The fertilizer subsidy which has been provided since 2005 was the main factor that contributed to this significant growth of paddy production. As paddy farming is the main economic activity in the rural sector, the growth of paddy production has clearly had a direct effect on the on the decline of poverty incidence in this sector.

\section{Income Inequality and Poverty}

Growth, income inequality and poverty are closely related phenomena. As mentioned above, the impact of growth on poverty depends on the distributional effect of growth with other factors.

Table 5. Share of GDP by Province

\begin{tabular}{lllllc}
\hline Province & $\mathbf{1 9 9 0}$ & $\mathbf{1 9 9 6}$ & $\mathbf{2 0 0 2}$ & $\mathbf{2 0 0 6}$ & $\mathbf{2 0 1 0}$ \\
\hline Western & 40.2 & 43.7 & 48.1 & 50.1 & 45.1 \\
Southern & 9.5 & 9.0 & 9.7 & 10.0 & 10.7 \\
Sabaragamuwa & 8.1 & 9.0 & 6.9 & 6.1 & 6.3 \\
Central & 12.1 & 10.0 & 9.4 & 8.8 & 10.0 \\
Uva & 8.1 & 5.1 & 4.3 & 4.3 & 4.5 \\
Eastern & - & - & - & 4.9 & 5.9 \\
North Western & 11.1 & 11.3 & 10.1 & 9.1 & 9.4 \\
North Central & 4.8 & 4.8 & 3.9 & 4.0 & 4.8 \\
Northern & - & - & - & 2.8 & 3.4 \\
\hline
\end{tabular}

Source: Department of National Planning, Central Bank of Sri Lanka, Annual Reports

Note: The shares of GDP do not add up to $100 \%$ up to 2002, since Northern and Eastern, Provinces are excluded for those years.

The regional disparity of poverty incidence and the variation in the decline of poverty rates across regions can be described based on the disparity in the share of each province to the GDP. According to Table 5, there is a significant regional variation in the share of the GDP across provinces. The Western Province alone contributes almost half of the national income. Its share has increased from around 40 per cent in 1990 to 45 per cent in 2010. In fact, it was 50 per cent in 2006. Southern, Central and Northwestern Provinces each contribute with approximately 10 per cent. The shares of Sabaragamuwa, Central and Uva Provinces have declined by 2010 compared with 1990, while the shares of the other provinces have either increased marginally or remained unchanged. Indeed, this regional disparity of the share of GDP is one of the reasons for the differences in income poverty across the regions.

\section{Unemployment and Poverty}

A sustained high level of economic growth contributed largely to create employment opportunities, thus reducing unemployment and poverty incidence. Table 6 below illustrates the unemployment of the country during the past two decades from 1990.

Table 6. Unemployment Rate 1990-2010

\begin{tabular}{llll}
\hline \multirow{2}{*}{ Year } & \multicolumn{3}{l}{ Unemployment rate (\%) } \\
\cline { 2 - 4 } & Total & Male & Female \\
\hline 1990 & 15.9 & 11.8 & 23.4 \\
1995 & 12.3 & 8.8 & 18.8 \\
2000 & 7.6 & 5.8 & 11.0 \\
2005 & 7.2 & 5.3 & 10.7 \\
2010 & 4.9 & 3.5 & 7.7 \\
\hline
\end{tabular}

Source: Central Bank of Sri Lanka, Annual Reports

As per table 6, over the past two decades, unemployment has declined remarkably from 15.9 percent in 1990 to 4.9 
percent in 2010. Unemployment among females has reduced sharply in the recent past. Undoubtedly, this decrease in unemployment among females has resulted in the increase of the females' contribution to the economy and a decreasing poverty incidence. Hence, a decline in unemployment could be identified as another factor that contributed to reduce poverty rates in the country recently.

\section{Workers' Remittance and Poverty}

The growth of remittances from migrant Sri Lankan workers working abroad is another factor that contributed to the reduction of poverty levels. Table 7 below shows the workers' remittances from the year 2000 and 2010. As per the table, workers' remittances have increased over fivefold from 87,697 million to 465,372 million during this period. Also, it can be noted that workers' remittances shows a consistently increasing trend. Over the period, remittances have increased by approximately 39 percent annually. The highest percentage of these remittances is from the Middle-East. In addition, the majority of the Sri Lankan workers in the Middle-East are females from low income families. These remittances reduce their poverty by increasing the income levels and uplifting the living conditions of their family members.

Table 7. Workers remittance: 2000-2010

\begin{tabular}{ll}
\hline Year & Rs million \\
\hline 2000 & 87697 \\
2005 & 195256 \\
2006 & 224663 \\
2007 & 276728 \\
2008 & 316118 \\
2009 & 382801 \\
2010 & 465372 \\
\hline
\end{tabular}

Source: Central Bank of Sri Lanka. Annual Reports

\section{Targeted Poverty Alleviation Programs and Poverty}

In addition to the social welfare programs, the public sector spends extensively on providing social safety nets to protect poor families from the competitive economic environment. Free education, healthcare and food subsidy were included in the major public sector welfare programs up to $1980 \mathrm{~s}$. With the transition of the economy from a regulated policy framework into the market friendly policy framework at the end of 1970s, the necessity of safety nets arose in order to protect the people who were unable to cope with the competitive market environment. While continuing free health and education, several other programs have been implemented since the 1980s in order to address this. Targeted poverty alleviation programs were initiated within this background. The Janasaviya Program implemented in 1989 is the first poverty alleviation program in the country. It was superseded by the Samurdhi program in 1995, the main poverty alleviation program operating at present. Income supplementary program, dry rations program, nutrition program and Samurdhi social security program are the main poverty alleviation strategies of the Samurdhi program. The number of beneficiary families under the income supplementary program is 1.5 while 60,000 were included in the nutrition program by 2010. Meanwhile, about 30,000 families have benefited from Dry ration program by this year. In addition to the Samurdhi program, Gamidiriya and Gamanaguma programs also operate in the whole country aiming at strengthening the economic base of the low income families. Undoubtedly, these efforts have made a significant contribution towards the reduction of poverty incidence in the recent past.

\section{Economic and Social Infrastructure}

Massive economic and social infrastructure development drives led by the public sector since 2005 are the crucial factors that affected the reduction in poverty incidence. One of the key strategies that the government implemented to achieve and sustain economic development was improving the economic infrastructure base of the country. Accordingly, the government invested substantially on various projects across the country including roads, ports, communication, energy, irrigation and water.

Table 8. Government Investment on Economic and Social Infrastructure

\begin{tabular}{llll}
\hline Year & $\begin{array}{l}\text { Economic services } \\
\text { \% of GDP }\end{array}$ & $\begin{array}{l}\text { Social Services } \\
\text { \% of GDP }\end{array}$ & $\begin{array}{l}\text { Total } \\
\text { \% of GDP }\end{array}$ \\
\hline 2005 & 3.2 & 2.5 & 5.7 \\
2006 & 3.6 & 1.6 & 5.2 \\
2007 & 3.9 & 1.5 & 5.4 \\
2008 & 3.8 & 1.4 & 5.2 \\
2009 & 5.3 & 1.1 & 6.4 \\
2010 & 5.0 & 1.0 & 6.0 \\
\hline
\end{tabular}

Source: Central Bank of Sri Lanka, Annual Reports

As shows in Table 8, the public sector investment on economic and social infrastructure as a percentage of GDP has increased over the years. By this, it was expected to expand the production capacity of the economy while increasing economic efficiency and reducing regional disparities, thereby helping to achieve a regionally balanced growth (CBSL, 2011:59). This is evident in the decrease of the share made to the GDP by the Western Province and the increase of the share contributed by other provinces (see Table 9). The development of infrastructure at the regional level integrated the rural and urban markets benefitting not only the rural poor but urban low income sector, too. Undoubtedly, such massive investments on economic infrastructure would create more benefits in the long-run and would help to reduce broad-based poverty in the future. 
Table 9. Provincial contribution to the GDP

\begin{tabular}{llllll}
\hline \multirow{2}{*}{ Province } & \multicolumn{6}{l}{ Contribution to the GDP } \\
\cline { 2 - 6 } & $\mathbf{2 0 0 6}$ & $\mathbf{0 0 7}$ & $\mathbf{2 0 0 8}$ & $\mathbf{2 0 0 9}$ & $\mathbf{2 0 1 0}$ \\
\hline Western & 50.1 & 46.5 & 45.4 & 45.8 & 44.8 \\
Central & 8.8 & 9.6 & 9.8 & 9.8 & 10.0 \\
Southern & 10.0 & 10.5 & 10.5 & 10.5 & 10.7 \\
Northern & 2.8 & 2.9 & 3.2 & 3.2 & 3.4 \\
Eastern & 4.9 & 5.2 & 5.6 & 5.8 & 5.6 \\
North Western & 9.1 & 9.9 & 9.9 & 9.6 & 9.5 \\
North Central & 4.4 & 4.4 & 4.7 & 4.6 & 4.8 \\
Uva & 4.3 & 4.9 & 4.5 & 4.5 & 4.5 \\
Sabaragamuwa & 6.1 & 6.4 & 6.4 & 6.1 & 6.3 \\
\hline
\end{tabular}

Source: Central Bank of Sri Lanka, (2013).

Economic and Social Statistics of Sri Lanka

Moreover, the government's view on social infrastructure was that it is vital to strengthen the human capital base resulting in productivity improvements and innovations which would drive the growth. Accordingly, many resources were allocated on welfare oriented socioeconomic programs including health, education, housing, sanitation and social safety nets. A part of these resources trickles down to the low income community as public expenditure, helping to reduce poverty among them in the short term. The upgraded social overhead will produce more benefits to the poor directly as well as multiplier process in the long run.

\section{Conclusion and Policy Discussion}

At the national level as well as sectoral level, poverty incidence in Sri Lanka has declined significantly during the past two decades. This decline is substantial since the early years of 2000s. As a whole, the depth of poverty has also declined considerably. Several contributory factors could be identified for this progress including economic growth, remittance from the workers in abroad, decline of unemployment, public sector poverty alleviation programs and investments on economic and social infrastructure.

Amidst these achievements, some challenges that should be addressed carefully can be identified. Among them, the disparity of poverty incidence among geographical locations still remains as a key issue. Sustaining the declining trend of poverty incidence is also a difficult task. Attention must be paid to the non-poor population just beyond the poverty line because this group exists in a highly vulnerable situation, since a minor negative impact on their income/consumption can cause many of them to fall back in poverty that result in a large increase in poverty incidence.

Moreover, for the eradication of broad based poverty incidence, other dimensions of poverty in addition to its income dimension should be addressed strongly. There are many grievances over the access to health and education services, housing and drinking water capabilities etc.

In the midst of these challenges, several opportunities have opened up particularly with the end of the war. This can be considered a great opportunity to attract large scale investment and to develop tourism and related industries.
Improved economic and social infrastructure would also help to produce more benefits to the nation and for the poor in the future. With the better and a more reliable policy framework, these opportunities could be translated into the socioeconomic progress and prosperity of the nation.

\section{References}

[1] Abeyratne, F. (2001). Poverty/Governance Nexus and its Relationship to the Status of the Small Farm Agriculture Sector in Sri Lanka. In Wijitapura Wimalaratana (ed.), Agriculture and Rural Development in Sri Lanka. Development Resource Centre, Department of Economics, University of Colombo.

[2] Angus Deaton, (2007). Measuring Poverty. In Banerjeee et al. (ed.), Understanding Poverty, Oxford University Press.

[3] Central Bank of Sri Lanka, Annual Reports in various years.

[4] Datt and Ravallion, (1998). Farm Productivity and Rural Poverty in India. Journal of Development Studies, April.

[5] Department of Census and Statistics, (2008). Household Income and Expenditure Survey - 2006/07. Department of Census and Statistics, Ministry of Finance and Planning.

[6] Department of Census and Statistics, (2011). Poverty Indicators; Household Income and Expenditure Survey 2009/10. 1, 2 .

[7] Doller, D. K. Kraay, (200). Growth is Good for Poor. World Bank, Washington DC.

[8] Government of Sri Lanka, (2002) REGAINING SRI LANKA: Vision and Strategy for Accelerated Development. December, 2002

[9] Kakwani, N and E M Pernia (2000). What is Pro-Poor Growth?. Asian Development Review. 18, 1.

[10] Mookherjee Dilip (2007). 'Poverty Persistence and Design of Antipoverty Policies', In Banerjeee et al. (ed.), Understanding Poverty, Oxford University Press.

[11] Semasinghe W. M. (2009). Public Welfare Policies and Rural Poverty in Sri Lanka. (Unpublished Doctoral Dissertation). University of Kelaniya. Sri Lanka.

[12] Semasinghe W. M. (2011). The Effects of Public Welfare Policies on Rural Poverty in Sri Lanka: A Logistic Regression Analysis'. Sri Lanka Journal of Advanced Social Studies, Vol.1 (1) 2011 145-179

[13] World Bank (2008). Sri Lanka Poverty Assessment. World Bank, Washington DC.

[14] DCS. Sri Lanka Poverty Review. Website: http://www.statistics.gov.lk/poverty/ SriLankaPoverty Review\%20_English.pdf

[15] UNDP. Eradicate extreme hunger and poverty where we are. Website: http://www.lk. undp.org/content/srilanka /en/home / mdgoverview/overview/mdg1/

[16] Ratha, Dilip and Sanket Mohapatra (2007). Increasing the Macroeconomic Impact Remittances on Development. Development Prospects Group. The World Bank. Washington D.C. 